\title{
Bibliotekarieyrket i förändring: en text- och diskursanalys
}

\author{
Av Pernilla Ragnarsson och Malin Svensson \\ studerande på programmet för Biblioteks- och informationsvetenskap \\ vid Växjö universitet
}

\section{Inledning}

Dagspressen har stor makt när det gäller att forma vår uppfattning om hur saker och ting förhåller sig. När det gäller bibliotekarier finns det många förutfattade meningar bland allmänheten. Hur bibliotekarier framställs i dagspressen påverkar allmänhetens uppfattning och bidrar till att en särskild bibliotekarieidentitet konstrueras. Diskursanalys innebär att man studerar samhällsfenomen genom att fokusera på språket som man menar formas i en social kontext och bestämmer vårt sätt att tänka och handla (Bergström \& Boréus 2000, s. 221f.). En diskursanalys kan därför fungera som ett verktyg för att identifiera hur en yrkesidentitet konstrueras och vem som har makten att göra detta.

\section{Syfte}

Syftet med denna text är att visa hur bibliotekarieidentiteten framställs i dagspressen under 1980-, 1990- och 2000-talet. Vi vill även se om bibliotekariediskursen har förändrats under denna tidsperiod.

\section{Metod}

Vi utgår från en foucaultiansk inriktning, där en diskurs ses som ett regelsystem som bestämmer vad som kan sägas, vem som får säga det och hur det kan sägas. Vi kommer därför att koncentrera oss på gemensamma drag i texterna och försöka urskilja förändringar eller så kallade diskursiva brott. Foucault hävdade att makt finns i alla sociala relationer, och att alla strävar efter att få sin kunskap erkänd som den rätta (Bergström och Boréus 2000, s. 226).

Vi har analyserat en nyhetsartikel från 1980-, 1990- respektive 2000-talet. Vi har undersökt texterna på olika nivåer genom att använda följande analysmetoder: lexikal analys, metaforanalys, syntaxanalys och argumentationsanalys. De tre förstnämnda ingår i vad Bergström och Boréus (2000) kallar för lingvistisk textanalys. Den lingvistiska textanalysen utgår från att vårt sätt att använda språket hänger ihop med vårt sätt att uppfatta omvärlden. Man inriktar sig på det gemensamma språkets styrande makt för vad som kan sägas och tänkas. Genom de olika analyssätten kan man avslöja eventuella ideologiska budskap som inte står klart uttryckta i texten (s. 179f.).

Lexikal analys innebär att man undersöker ordvalet i en text genom att lyfta fram värdeladdade ord och se vilka ord som används i ett visst sammanhang. Med hjälp av en lexikal analys vill vi undersöka med vilka ord bibliotekarier och deras arbete beskrivs i artiklarna.

En metaforanalys kan säga något om texters innebörd och vilka tankemönster som ligger bakom. Metaforer är överföringar från ett område till ett annat, som inte är nära förknippade (Bergström och Boréus 2000, s. 181). Man skiljer mellan aktiva metaforer, som är 
nyskapade uttryck, och inaktiva metaforer, som är mer konventionella eller fasta språkliga uttryck. Enligt Bergström och Boréus (2000) kan inaktiva metaforer visa på diskursiva mönster som varken avsändare eller mottagare av en text kanske är medvetna om (s. 185f.). Vi vill undersöka om, och i så fall vilka, metaforer som används för att beskriva bibliotekarierna och deras arbete.

I en syntaxanalys undersöker man texters meningsbyggnad för att se hur skeenden beskrivs. Man kan undersöka om ett skeende eller en process beskrivs som en handling eller en händelse. Deltagare i processer kan vara agenter som handlar, eller deltagare som påverkas, vilka kan vara mänskliga (mottagare) eller icke mänskliga (objekt). Om ett skeende beskrivs som en handling ges agenterna i processen ansvar för det som har hänt, men om det däremot beskrivs som en händelse ligger ansvaret utanför agenterna (Ibid., s. 200). Eftersom vi är intresserade av vilka deltagarroller som bibliotekarierna intar i texterna fokuserar vi på om de är agenter eller mottagare i de processer som de direkt eller indirekt deltar $\mathrm{i}$.

Argumentationsanalys kan användas för att undersöka hur kommunikationen i en text är utformad. En argumenterande text vill alltid övertyga läsaren om något. Genom att argumentationen synliggörs kan man få en överblick av vem som säger vad och hur det sägs. Detta kan säga något om vilka som har makten att uttala sig och därmed upprätthålla diskursen. Vi vill undersöka om information om bibliotekarierna hävdas i teser och argument, och om så är fallet vad det är som hävdas.

\section{Material}

De texter som ingår i vår undersökning är Magnus Knutssons "Ut och tala bland vuxna bibliotekariens nya roll" från 1983 (Text 1), Anna Danielssons "Få vill bli bibliotekarier" från 1990 (Text 2), samt Lars Johanssons "Bibliotekariens nya roll" från 2002 (Text 3).

Den första texten är en intervju med Britta Dreborg, barnbibliotekskonsulent, och Lena Skoglund, lärare vid Bibliotekshögskolan. Syftet med artikeln är att framhålla barnbibliotekariens förändrade yrkesroll. Två särskilda yrkesspråk kan urskiljas, journalisternas och bibliotekariernas, vilket kan ha att göra med att artikeln är utformad som en intervju där journalisten ställer frågor och bibliotekarierna svarar. Journalistens språk är exempelvis rakt på sak och lite provocerande. Bibliotekarierna i sin tur använder för dem typiska uttryck som "pärlorna" och "topparna" när de talar om böcker. Texten är förankrad i både journalistens generaliserande bild av bibliotekarier och bibliotekariernas syn på den egna yrkesrollen.

Den andra texten är beroende av en viss aktuell händelse, nämligen att utbildningsplatser på Bibliotekshögskolan står tomma. Artikelns syfte är att visa på anledningar till varför det är få som vill bli bibliotekarier. I den här texten kan framförallt ett typiskt journalistiskt språk urskiljas, det är korthugget och rakt på sak. Något som är typiskt för nyhetsartiklar är att man ofta hänvisar till faktauppgifter, vilket är fallet i denna. Liksom i den förra texten är denna förankrad i bibliotekariens sätt att se på sin yrkesroll.

I den tredje texten är syftet att visa hur utbildningen har påverkats av de förändringar som bibliotekarieyrket har genomgått. Även i den här texten kan man urskilja ett typiskt journalistiskt språk. I texten kan man urskilja ett studentperspektiv, eftersom den utgår från Bibliotekshögskolans studenter och inte yrkesverksamma bibliotekarier.

\section{Resultat}

Vid en lexikal analys av den första texten ser vi att journalisten beskriver bibliotekarierna som "snälla tanter som läser sagor", medan bibliotekarierna talar om sig själva som "litteraturexperter". På några ställen i texten ersätter ordet bibliotek själva bibliotekarierna, till exempel "biblioteket köper in". Det är bibliotekarierna som köper in, men här har 
skribenten valt ett annat ord för dem. I denna text är det enbart barnbibliotekarier som ingår i begreppet bibliotekarie. Journalisten beskriver även bibliotekariernas arbete med negativt laddade värdeord, som exempelvis att de "bara håller på med" något. I den andra texten beskriver bibliotekarier yrket som ett "kvinnoyrke" med dålig lönebildning. Yrket beskrivs implicit som ett lågstatusyrke, annars skulle yrkets status inte behöva höjas. Enligt bibliotekarierna i artikeln har allmänheten en bild av att bibliotekarien "mest hasar omkring och plockar bland böckerna". I begreppet bibliotekarie ingår här de som är utbildade bibliotekarier. I den tredje texten talas det om bibliotekarierna som "biblioteks- och informationsvetare" och "informationsmäklare". De beskrivs bland annat som "experter" på att samla och sammanställa information. Ordet expert är exempel på ett positivt laddat ord. Negativt laddade värdeord används också för att beskriva yrket, till exempel att det förlorar "bredd och djup" och att det är "mer yta än innehåll". Även här är det utbildade bibliotekarier som ingår i begreppet bibliotekarie.

Metaforer används i samtliga texter för att beskriva bibliotekariernas arbete. I den första texten utgör Biblioteket är en container en begreppslig metafor. Exempel på metaforiska uttryck som ingår i denna är bland annat "sitta på biblioteken", "gå ut i samhället" och "lämnar biblioteket". Exempel på metaforiska uttryck i den andra texten är "vänder ryggen", "står tomma", "höja yrkets status" och "bredda allmänbildningen". I den tredje texten förekommer metaforiska uttryck som "i ropet", "arbetsfält öppnas" och "förädla information". En begreppslig metafor för det sistnämnda kan vara att Bibliotekarien är en alkemist. Bibliotekariens kunskap är en källa utgör ännu en begreppslig metafor i den tredje texten och metaforiska uttryck som ingår i denna är "bibliotekarierna förlorar bredd och djup" och "grundare kunskaper". Samtliga metaforer i texterna är inaktiva. Sådana är utmärkande för det journalistiska språket.

Vid en analys av syntaxen i texterna kan man se att i både den första och den andra texten består processerna nästan enbart av handlingar där bibliotekarierna är agenter. Även i den tredje texten utgör bibliotekarierna till största del agenter i processerna, men här är de jämnt fördelade på handlingar och händelser. De finns även med som dolda agenter i betydligt högre utsträckning än i de tidigare texterna. Det rör sig framförallt om processer som beskrivs som att-fraser, det vill säga satsförkortningar. Ett exempel på detta är "biblioteks- och informationsvetare är experter på att samla och sammanställa relevant information", där det inte är utskrivet vem som samlar eller sammanställer. Det är dock underförstått att det är biblioteks- och informationsvetarna som gör detta. Bibliotekarierna är dessutom mottagare i ett fåtal handlingar och händelser i den tredje texten.

I samtliga texter hävdas information om bibliotekarierna i teser och argument. I den första texten kan tesen formuleras som "Bibliotekarien ska ut och tala bland vuxna". Tesen är normativ. Det är någon som uttrycker denna åsikt och därmed innehåller tesen en värdering (Bergström \& Boréus 2000, s. 96). Artikeln innehåller både för- och motargument. Argument för tesen är exempelvis att barnbibliotekariernas kunskaper måste föras vidare till dem som bäst når barnen, det vill säga föräldrar och lärare. Ett annat argument för är att rollen att föra ut boken är den viktiga. Argument mot tesen är att bibliotekarierna kommer att få mindre tid att vara på sin arbetsplats. Ett annat motargument är att sättet att arbeta kommer att påverka litteratururvalet. I den andra texten utgörs tesen av "Få vill bli bibliotekarier". Tesen är faktuell, eftersom den vilar på fakta och är värderingsfri (Ibid., s. 96). Till skillnad från den förra artikeln förekommer i denna endast argument för tesen. Exempel på argument är exempelvis att utbildningsplatser på Bibliotekshögskolan i Borås står tomma och att det finns andra mer välbetalda jobb. Tesen i den tredje texten är "Utbildningen har påverkats av att yrket är i förvandling". Den är normativ. Även i denna artikel förekommer endast argument för tesen, till exempel att studenter i biblioteks- och informationsvetenskap nu har mindre tid för studier av skönlitteratur på schemat än tidigare.

\section{Slutsats}


Genom en närläsning och analys av våra tre artiklar har vi kunnat dra följande slutsatser. I en lexikal analys framkommer det att bilden av bibliotekariens sociala identitet har förändrats över tidsperioden. Beskrivningen av bibliotekariens yrkesroll har gått från sagotant och lågstatusyrke till experter och informationsmäklare. I den senaste artikeln talar man inte längre om bibliotekarier utan om biblioteks- och informationsvetare. Att bibliotekarierna själva beskriver sitt arbete som ett lågstatusyrke på 1990-talet kan ha avgörande betydelse för hur den sociala identiteten konstrueras. I de två första artiklarna beskriver både journalisten och bibliotekarierna en slags schablonbild av bibliotekarien. Även om bibliotekarierna hävdar att den inte stämmer, befäster de den genom att de uttrycker den. Vem som säger vad kan ha stor betydelse för hur diskursen konstrueras. I den senaste artikeln talar man inte längre om någon schablonbild av bibliotekarien. Redan på 1980-talet talar bibliotekarierna om sig själva som experter, men det är inte förrän på 2000-talet som journalisterna riktigt har anammat detta synsätt. Eftersom det i slutändan är de som bestämmer över det slutgiltiga resultatet skulle man kunna hålla dem ansvariga för hur bibliotekariediskursen har formats i dagspressen.

I den första texten används ordet bibliotek flera gånger istället för bibliotekarie. Till och med en av bibliotekarierna säger att "Rollen att föra ut barnboken är den viktiga" i samband med att bibliotekets roll måste preciseras. Vad hon egentligen menar är bibliotekariernas roll. Det finns alltså en tendens att glömma bort dem som utför arbetet på ett bibliotek. Bibliotekariens roll blir på så sätt osynlig.

De inaktiva metaforerna är typiska för det journalistiska språket. Därför är det inte förvånande att bibliotekarierna och deras arbete framställs genom inaktiva metaforer i nyhetsdiskursen. Nästan samtliga metaforer pekar på fysiska eller konkreta egenskaper i bildledet för att beskriva psykiska eller mer abstrakta egenskaper i sakledet. Detta kan ha att göra med att bibliotekarier inte artikulerar det arbete som de utför, vilket gör att det uppfattas som abstrakt och svårt att sätta ord på. Vid en jämförelse av de begreppsliga metaforerna i den första och den tredje texten kan vi se en förskjutning från bibliotek till bibliotekarier. Bibliotekarier behöver inte nödvändigtvis förknippas med biblioteksbyggnaden och deras roll har synliggjorts.

Att bibliotekarierna är agenter i högre utsträckning i den första och den andra texten än i den tredje beror säkert delvis på att de kommer till tals genom att de blir intervjuade. I den tredje texten kommer inte bibliotekarier direkt till tals, utan det är om dem det talas. Anledningen till att bibliotekarierna till stor del fungerar som dolda agenter i den tredje texten kan ha att göra med bibliotekarieyrkets förändring. Bibliotekariernas arbete har blivit mer osynligt i och med att det har förflyttats från lånedisken ute i biblioteket till datorn inne på arbetsrummet. En annan anledning till detta kan vara akademiseringen av yrket, biblioteks- och informationsvetenskap har blivit en egen vetenskaplig disciplin. Den tredje texten fokuserar på ämnet biblioteks- och informationsvetenskap, och inte på bibliotekarier. Vi uppfattar att den största förändringen i bibliotekariediskursen ligger här, och denna förändring kan ses som ett diskursivt brott.

Att information om bibliotekarierna och deras arbete hävdas i teser och argument säger i sig något om bibliotekariediskursen. I den första artikeln ifrågasätter journalisten bibliotekariens nya roll och vad som ingår i denna. Det är inte något som är självklart. Att bibliotekarierna måste argumentera för sin yrkesroll är märkbart. I den andra artikeln argumenteras det för varför det är få som vill bli bibliotekarier, men det lyfts inte direkt fram några argument som talar för varför man ska bli bibliotekarie. I den senaste artikeln råder det inte längre någon tvekan om vad bibliotekarieyrket innebär. Vi märker en skillnad i hur argumentationen förs i de olika texterna, och kan därmed säga att bibliotekariediskursen har förändrats. Även om bibliotekariernas uttryck och synsätt spelar roll, är det till största del journalisterna som styr och har makten att konstruera bibliotekariediskursen i dagspressen. 


\section{Källor}

Bergström, G. och Boréus, K. (2000). Textens mening och makt. Lund: Studentlitteratur. Danielsson, A. (1990, 22 augusti). Få vill bli bibliotekarier. Svenska Dagbladet, Del 2, s. 4. Knutsson, M. (1983, 28 maj). Ut och tala bland vuxna bibliotekariens nya roll. Dagens Nyheter, På stan, s. 28.

Johansson, L. (2002, 3 december). Bibliotekariens nya roll. Dagens Nyheter, Del A, s.13. 